\title{
A Survey on the Effect of Service Delivery System on Corporate Performance Using Service Profit Chain Model
}

\author{
Alireza Fazlzadeh \\ College of Economics and Management, University of Tabriz \\ $29^{\text {th }}$ Bahman Street University of Tabriz, Tabriz, Iran \\ Tel: 98-91-4404-2925Ｅ-mail: fazlzadeh_acc@yahoo.com
}

Mohammad Faryabi

College of Economics and Management, University of Tabriz

$29^{\text {th }}$ Bahman Street University of Tabriz, Tabriz, Iran

Tel: 98-91-4116-2570_E-mail: infofaryab@yahoo.com

Hossein Alizadeh Darabi (Corresponding author)

College of Economics and Management, University of Tabriz

$29^{\text {th }}$ Bahman Street University of Tabriz, Tabriz, Iran

Tel: 98-91-4443-4756 E-mail: husen_alizadeh@yahoo.com

Behrad Zahedi

College of Economics and Management, University of Tabriz

$29^{\text {th }}$ Bahman Street University of Tabriz, Tabriz, Iran

Tel: 98-91-2375-5594Ｅmail: behrad.zahedi@gmail.com

\author{
Received: November 17, $2011 \quad$ Accepted: December 22, $2011 \quad$ Published: March 16, 2012 \\ doi:10.5539/ijbm.v7n6p161 \\ URL: http://dx.doi.org/10.5539/ijbm.v7n6p161
}

\begin{abstract}
One of the unique characteristics of services is that customer participate actively in service production process. In other words, every moment is the interaction between a customer and a supplier of services, that each part plays crucial role in service- based organizations. Such models have been proposed to explain this interaction, the service profit chain model. Service profit chain model offers a relation which connects organization profit, customer loyalty and service value to the employee satisfaction, productivity and ability. In this study Service delivery system presented by variables such as employee satisfaction, employee loyalty, the quality of services provided by employees and employee capability. In The designed model customer satisfaction considered as intermediate variables impact organizational performance in service delivery systems as well as customer loyalty.

The results of the analysis of field data brokerage companies in Tehran Stock Exchange showed a significant effect of service delivery system on customer satisfaction and loyalty. The results also showed that customer satisfaction and loyalty have significant effect on the performance of brokers that are in the Tehran Stock Exchange. Impact of employee satisfaction and employee capabilities on customer satisfaction has been confirmed. And the impact of employee satisfaction, service quality and employee capability on customer loyalty has been confirmed.
\end{abstract}

Keywords: Service delivery system, Service profit chain, Customer satisfaction, Customer loyalty and organizational performance 


\section{Introduction}

The causal relationship between employee satisfaction, customer satisfaction, and profitability is a topic of growing academic and managerial interest (e.g. Oliver, 1997; Reichheld, 1993; Rust et al., 1996; Estelami, 2000; Heskett et al., 1997). This stream of research has helped conceptualize the notion of a "service profit chain" (Heskett et al., 1994, 1997), within the service profit chain, service quality is driven, primarily, by employee satisfaction, which, in turn is influenced by HR practices. The overall chain sees service quality driving customer satisfaction which creates customer loyalty leading to growth and profit. The original propositions were based on research in 20 large service organisations and subsequent research has broadly supported the proposed linkages (Loveman, 1998; Rucci et al., 1998; Brooks, 2000; Anderson and Mittal, 2000).

In relation to staff management and efficient use of corporate resources, internal quality of an organization has a special place. The internal quality of an organization means the level of environment that employees work in it. The satisfaction of the employees of the internal quality of the Organization will maintain them and increase their efficiency. And this is also in turn caused the value of the services will be filed under instrument gain the satisfaction of our customers and their loyalty. With customer satisfaction and loyalty organization will be able to obtain better performance in competition. The question that raised here is whether paying attention to the properties of the different staff and gain the satisfaction of the workers can be effective on providing the services that led to customer satisfaction and loyalty? And whether employees are satisfied with the quality of internal organization is associated with satisfaction and loyalty of costumers? And whether getting and keeping customers satisfied and loyal can improve performance of service organizations?

The above questions and relations existing between the variables above is the issue that is in the service profit chain model and consequently in this study. Thus it can be the main objectives of the research in the following summary.

- Reviews the impact of service delivery system on customer satisfaction;

- Reviews the impact of service delivery system on customer loyalty;

- Reviews the impact of customer satisfaction on the performance of the stock brokerage institutions;

- Reviews the impact of customer loyalty on the performance of the stock brokerage institutions.

The remainder of the paper is organized as follows. Section 1 provides a literature review of the service profit chain framework and affect of service delivery system on performance. Section 2 describes the research methodology to carry out the empirical work. Finally Section 3, the analysis and managerial implications of the results are presented and discussed.

\section{Literature review}

Heskett et al.'s (1997) service profit chain postulates a chain of performance relationships commencing with a circle of internal service quality, service capability, employee satisfaction and loyalty, productivity and output quality; which in turn drive service value, customer satisfaction and loyalty, leading to enhanced revenue growth and/or profitability(Pritchard and Silvestro, 2005).

In this framework internal improvements are posited to positively affect employees resulting in a more productive workforce capable of enhancing the quality of the service offering. This quality/offering improvement is expected to result in an increased value perceived by customers, which, in turn, leads to higher levels of satisfaction, long-term loyalty, and profitability. The service profit chain is an effective framework to structure the complex inter-relationships between employee perceptions, customer perceptions, and the associated organizational performance. Utilization of the service profit chain as an investigation framework is not uncommon, as it has been used as the method for exploring the performance of retail outlets (Pritchard and Silvestro, 2005), transportation service satisfaction (Anderson et al., 2004), and employee development initiatives (Goldstein, 2003).

\subsection{Internal service quality is related to employee satisfaction}

Heskett et al. (1994) referred internal service quality to the quality of work environment that contributes to employee satisfaction, which has also been known as "quality of work life" or QWL (Lau, 2000). QWL is defined as the favorable conditions and environments of a workplace that support and promote employee satisfaction by providing them with rewards, job security, and growth opportunities.

Locke (1976) defined employee satisfaction as a pleasurable or positive emotional state resulting from the appraisal of one's job or job experiences. There are many similarities between the customer and employee satisfaction processes. Customer needs and wants are satisfied when they perceive goods and services to have 
value that meets or exceeds their expectation (Anderson and Sullivan, 1993). Likewise, employee needs and wants are satisfied when they perceive that rewards from the organization, including compensation, promotion, recognition, development, and meaningful work, meet or exceed their expectation (Hackman and Oldham, 1980). Rust and Stewart (1996) proposed using a customer satisfaction measurement approach to evaluating employee satisfaction and retention. The results of their study illustrated how the field of human resource management can benefit from recent advances in the area of customer satisfaction measurement.

\subsection{Employee satisfaction is related to employee loyalty}

Numerous studies on employee turnover support a negative relationship between employee satisfaction and turnover and at least three meta-analyses (Carsten and Spector, 1987; Hom and Griffeth, 1995; Steel and Ovalle, 1984) also confirmed such a relationship. A study by Schlesinger and Zornitsky (1991) showed that the potential turnover rate of unsatisfied employees is three times higher than that of satisfied employees. Increasing employee satisfaction and thereby reducing employee turnover is critical.

Employees with valuable work skills and experience are increasingly hard to recruit because the demand of such service workers continues to outpace the supply. As a result, it is imperative for organizations to retain their employees by nurturing a work environment that promotes their job satisfaction. Management is still struggling to come up with an effective way to measure and improve employee satisfaction due, in part, to a lack of valid instruments (Lau, 2000).

\subsection{Employee loyalty is related to employee productivity}

Through their long tenure services, loyal employees tend to develop personal relationships with their customers (Lau, 2000). These relationships serve as the foundation for a reinforcing cycle of positive interactions between the service employees and customers (Reichheld, 1993). Especially for industries of personal and professional services, the retention of employees who develop continuing positive relationships with their customers is critical. Choosing the right employees is the first step in retaining productive employees. Loyal employees are those who can fit in with each other within the same organization. One commonly used approach for recruiting loyal employees is to focus more on the applicants' attitude rather than skills during the recruitment process. A person's attitude can seldom be taught but skills can be instilled after hiring. The other approach is to filter out early in the hiring process those who are unlikely to stay on the job (Lau, 2000).

\subsection{Service delivery system is related to customer satisfaction}

Satisfaction refers to the customer's own experiences of a service where outcome has been evaluated in terms of what value was received. Customers today are strongly value-oriented and they seek results and service process quality that far exceed the price and acquisition costs they incur for that service (Heskett et al., 1997). Many people may equate value with quality for achieving customer satisfaction. It is possible that service quality can be judged low but the customers are still satisfied. This might be the case when the service price falls within the customer's budget or the service has already been priced according to the low quality (Lau, 2000).

Satisfied customers are an important goal and an important asset for successful organizations. When customers believe they have received a high service value from one service provider they are more likely to display loyalty behavior, including relationship continuance, increased scale or scope of relationship, and recommendations (word of mouth advertising) for that service provider (Hallowell, 1996).

\subsection{Service delivery system is related to customer loyalty}

Service providers are expected to increase their service value over time because customers today are very knowledgeable in seeking out new service alternatives and will defect if they are just merely satisfied(Lau, 2000). "Very satisfied" customers were found to be six times more likely to repurchase than those who were just "satisfied" (Jones and Sasser, 1995). Other studies, such as Gummesson (1993) and Storbacka et al. (1994) also discussed the link between satisfaction and loyalty. In the marketing literature, the impact of customer satisfaction on customer loyalty has been thoroughly explored. Yi (1990) reviewed many studies and concluded that customer satisfaction would influence purchase intention and post-purchase attitude. Jacoby and Kyner (1973) suggested that customer loyalty can be defined in two distinct ways: attitudinal and behavioral. Attitudinal loyalty refers to the customer's overall attachment to a product, service, or organization. On the other hand, behavioral loyalty refers to the purchasing habits from the same provider, increasing the scale and scope of a relationship (Lau, 2000).

\subsection{Customer loyalty and customer satisfaction are related to performance}

Loyal customers often account for an unusually high proportion of the sales and profit growth of a service 
organization. In addition, serving experienced customers will result in higher productivity for the service providers because those customers have become familiar with an organization's service delivery system. As a result, loyal customers can contribute to the productivity gain of the service delivery system by making suggestions for improvement or just simply being more cooperative(Lau, 2000). Heskett et al. (1997) emphasized the importance of evaluating the lifetime value of a customer. Service providers need to think about how to retain customers in a continuing, active relationship through a customer-oriented "three R's" of marketing: retention, related sales, and referrals. Growth and profitability of a service organization depend on how well the service providers are able to sell new services to existing customers and whether the customers will give positive referrals to potential customers. Reichheld and Sasser (1990) studied the effect of customer loyalty on profitability in a wide range of industries and they determined that customer loyalty is a more important factor of profit than market share. Furthermore, they found a five-percentage point increase in customer loyalty could produce a profit increase of 25 to 85 percent.

\section{Methodology}

\subsection{Research model}

Heskett et al.'s (1994) proposed service profit chain model to connect organization profit, customer loyalty and service value to the employee satisfaction, productivity and ability. In this research, some variables of the Heskett's model omitted. The research conceptual model is presented in the figure 1.

\subsection{Hypothesis}

The aim of this paper is to study how service delivery system effects customer satisfaction and loyalty as well as impact of these two variables on performance. To satisfy this need and after reviewing the literature we form the research hypothesis as follow:

H1: Service delivery system has a positive impact on the level of customer satisfaction.

H2: Employee satisfaction has a positive impact on the level of customer satisfaction.

H3: Employee loyalty has a positive impact on the level of customer satisfaction.

H4: Employee capability has a positive impact on the level of customer satisfaction.

H5: Quality of services has a positive impact on the level of customer satisfaction.

H6: Service delivery system has a positive impact on the level of customer loyalty.

H7: Employee satisfaction has a positive impact on the level of customer loyalty.

H8: Employee loyalty has a positive impact on the level of customer loyalty.

H9: Employee capability has a positive impact on the level of customer loyalty.

H10: Quality of services has a positive impact on the level of customer loyalty.

H11: Customer satisfaction has a positive impact on the level of brokerage performance.

H12: Customer loyalty has a positive impact on the level of brokerage performance.

\subsection{Data and sample}

The sample of research was Tehran stock exchange broker. The most important reason for choosing the brokerage community in the stock market is the bold role of the brokerage in the economy of the country and at the same time the availability of their information. In terms of time limits is also present in the six-month second year 2010 to do. And this research conducted in the second half of 2010.

Due to the qualitative nature of the variables and their multiplicity, to determine the appropriate sample size in order to ensure accuracy of results Cochran formula had used in the form below:

$$
n=\frac{\mathrm{NZ}\left(\frac{\alpha}{2}\right)^{2} \mathrm{P}(1-\mathrm{P})}{(\mathrm{N}-1) \varepsilon^{2}+\mathrm{Z}\left(\frac{\alpha}{2}\right)^{2} \mathrm{P}(1-\mathrm{P})}
$$

Using this formula the suitable sample size for doing the research obtained 49 companies. After determining the sample size, brokerages have been selected through a simple random sampling. According to the subject of research and variables, the required information for test hypothesis was collected through a questionnaire. The questionnaires filled by the senior manager of each brokerage. The final questionnaire contained four main parts in connection with the research variables. The table (1) shows variables and indicators used for measure each 
one.

\section{Results}

We evaluate our construct measurement in this study by examining the reliability and validity of the measurement scale. To examine reliability, we consider cronbachs alpha, by using SPSS software that is presented in table (2). Since Cronbach's alpha (0.838) is larger than 0.6, the reliability is acceptable.

\subsection{Reviews the impact of the service delivery system to the customers satisfaction}

According to the type of variables that are ordinal multi-values, in this study spearman correlation test was used. Spearman correlation coefficient shows the intensity of linear relationship between two variables when both variables are ordinal or interval type (mehralizadeh, 2005, p. 59). Spearman correlation test for variables "employee satisfaction", "employee loyalty", "employee capability", "service quality" and customer satisfaction shows that these variables, respectively, with a correlation coefficient of $0.482,0.47,0.602$ and 0.48 have significant and direct relationship with customer satisfaction. Even though the correlation coefficient shows intensity of the relationship between two variables, but cannot show the rate of change in the dependent variable when simultaneously affect from several independent variables. In these situations, multiple regression analysis helps the researcher to know how much of the variance in the dependent variable is explained by the same set of predictors. Therefore, to test the overall validity of the model, multiple regressions have been used. In order to test the hypothesis below multiple regressions analysis was conducted.

- The service delivery system has a positive impact on customer satisfaction.

- Employee satisfaction has a positive impact on customer satisfaction.

- Employee loyalty has a positive impact on customer satisfaction.

- Employee capability has a positive impact on Customer satisfaction.

- Quality of services has a positive impact on customer satisfaction.

In the estimated regression, associated components with the service delivery system are the independent variables and dependent variable is customer satisfaction. According to Watson test statistic obtained from ANOVA analysis and tolerance level (table 3), independence of errors and the linear nature of the relationship between variables confirmed. Therefore, the regression analysis and interpretation of results will be possible. Results of regression analysis are presented in Table (3).

The obtained regression shows the effect of four components of the service delivery system on customer satisfaction. According to that $\mathrm{R}^{\wedge} 2=0.492$, and $\mathrm{F}=10.91$ in significance level 0.000 can be claimed that identified four factors significantly affect customer satisfaction. The 0.50 of the changes in customer satisfaction are explained by the variables entered in the model. Also, according to the Standardized Beta and obtained sig, the following results for each of these factors can be expressed.

1) Service delivery system has a positive impact on the level of satisfaction of customers: according to model confirmation, level of $\mathrm{F}$ test which is equal to 10.91 and at the significant level of $95 \%$, can be claimed that this hypothesis is not rejected, and in fact Service delivery system has a positive impact on satisfaction of the customer.

2) Employee satisfaction has a positive impact on customer satisfaction: According to the level of B for this variable which is 0.303 and at the level of the meaning $95 \%$ that statistically has been approved, can be claimed that this hypothesis is not rejected, and in fact satisfaction of the employees has an positive and meaningful impact on the level of satisfaction of customers.

3) Employee loyalty has a positive impact on customer satisfaction: According to the level B for this variable which is 0.154 at the level of the meaning $95 \%$ is not approved statically, this hypothesis is rejected and in fact the loyalty of employees has not positive and meaningful impact on customer satisfaction.

4) Employee capabilities has a positive impact on customer satisfaction: According to the level of B for this variable which is 0.38 at the level of the meaning $95 \%$ that statistically has been approved, can be claimed that this hypothesis is not rejected, and in fact employees capabilities has an positive and meaningful impact on the level of satisfaction of customers.

5) Service quality has a positive impact on customer satisfaction: According to the level B for this variable which is 0.173 at the level of the meaning $95 \%$ is not approved statically, this hypothesis is rejected and in fact the service quality has not positive and meaningful impact on customer satisfaction. 


\subsection{Reviews the impact of service delivery system on customer loyalty}

As previously mentioned, "employee satisfaction", "employee loyalty", "employees capabilities" and "service quality" are components that make up the service delivery system. The results of Spearman correlation test for these variables and customer loyalty showed that these variables, respectively, with a correlation coefficient of $0.496,0.546,0.786$ and 0.596 had significant and direct relationship with customer loyalty.

As mentioned previously, correlation analysis is a statistical tool to determine the type and degree of linear relationship between two variables. It shows the severity and type of relationship (direct or inverse) between two variables. The results of the regression in Table (4) had been derived as follows. In order to test the hypothesis below this test is conducted.

The obtained regression shows the effect of four components of the service delivery system on customer loyalty. According to that $\mathrm{R}^{\wedge} 2=0.77$, and $\mathrm{F}=35.337$ in significance level 0.000 can be claimed that service delivery system affect customer loyalty. So it could be said that 0.77 of the changes in customer loyalty are explained by the variables entered in the model. Thus the above results for the hypotheses considered, can be stated as follows:

1) Service delivery system has a positive impact on the level of loyalty of customers: according to model confirmation, level of $\mathrm{F}$ test which is equal to 35.337 and at the significant level of $95 \%$, can be claimed that this hypothesis is not rejected, and in fact Service delivery system has an impact on loyalty of the customer.

2) Employee satisfaction has a positive impact on customer loyalty: According to the level of $B$ for this variable which is 0.0 .268 at the level of the meaning $95 \%$ that statistically has been approved, can be claimed that this hypothesis is not rejected, and in fact satisfaction of the employees has an positive and meaningful impact on the level of loyalty of customers.

3) Employee loyalty has a positive impact on customer loyalty: According to the level B for this variable which is 0.06 at the level of the meaning $95 \%$ is not approved statically, this hypothesis is rejected and in fact the loyalty of employees has not positive and meaningful impact on customer loyalty.

4) Employee capabilities has a positive impact on customer loyalty: According to the level of B for this variable which is 0.603 at the level of the meaning $95 \%$ that statistically has been approved, can be claimed that this hypothesis is not rejected, and in fact employees capabilities has positive and meaningful impact on the level of satisfaction of loyalty.

5) Service quality has a positive impact on customer loyalty: According to the level B for this variable which is 0.234 at the level of the meaning $95 \%$ that statistically has been approved, can be claimed that this hypothesis is not rejected, and in fact service quality has positive and meaningful impact on the level of customer loyalty.

\subsection{The effect of customer satisfaction and loyalty on the performance of brokerage active in the Stock Exchange}

As previously mentioned, in the designed model, performance of brokers which are in the stock exchange market is dependent variable. The results of Spearman correlation test for these three variables shows that customer satisfaction and loyalty respectively, with a correlation coefficient of 0.74 and 0.84 have significant and direct relationship with brokerage performance. In the final section to examine the extent of the impact of customer loyalty and customer satisfaction variables on the performance of the brokerage multiple regression estimate was used. The results of the regression in Table (5) are derived as follows. In order to test the hypothesis below this test is conducted:

- Employee satisfaction has a positive impact on brokerage performance.

- Employee loyalty has a positive impact on brokerage performance.

According to the table (5), customer satisfaction and loyalty has a significant impact on brokerage performance. In other words, according to the calculated coefficients at column Beta with increasing per unit at the level of satisfaction and loyalty of clients, performance of the brokerage respectively increases 0.278 and 0.644 of a unit. The above results for the hypotheses can be considered to be stated as follows:

1) Customer satisfaction has a positive impact on brokerage performance: according to model confirmation and the level of standardized B for this variable which is 0.278 at the level of the meaning $95 \%$ that statistically has been approved, it can be claimed that this hypothesis is not rejected, and in fact customer satisfaction has an impact on brokerage performance.

2) Customer loyalty has a positive impact on brokerage performance: according to model confirmation and the level of standardized B for this variable which is 0.644 at the level of the meaning $95 \%$ that statistically has been 
approved, it can be claimed that this hypothesis is not rejected, and in fact customer loyalty has an impact on brokerage performance.

The final results of the hypotheses testing are summarized in the table 6 .

\section{Conclusion}

In this study service delivery system has been reviewed and its effects on customer satisfaction and loyalty as well as impact of these two variables on performance have been tested. The results obtained suggest the existence of meaningful impact of service delivery system on satisfaction and loyalty of customers and the effect of these two variables on the performance of the brokerage. As previously mentioned, theoretical principles of this research was based on service profit chain model "James El.Heskett".

According to this model and the results of this research can be such an argument that with the improvement of the level of satisfaction, loyalty, capability and service quality of employees, brokerage customers ' satisfaction and loyalty also grows. So Creation of appropriate service delivery system led to having satisfied and loyal customers which can result growth in brokerage performance in Iran.

\section{References}

Anderson, E. W., \& Mittal, V. (2000). Strengthening the satisfaction-profit chai. Journal of Service Research, 3(2), 107-20. http://dx.doi.org/10.1177/109467050032001

Anderson, E. W., \& Sullivan, M. W. (1993). The antecedents and consequences of customer satisfaction for firms. Marketing Science, 12(Spring), 125-43. http://dx.doi.org/10.1287/mksc.12.2.125

Brooks, R. (2000). Why loyal employees and customers improve the bottom lin. Journal of Quality and Participation, 23(2), 40-4.

Carsten, J. M., \& Spector, P. E. (1987). Unemployment, job satisfaction and employee turnover: a meta-analytic test of the Muchinsky model. Journal of Applied Psychology, 72, 374-81. http://dx.doi.org/10.1037/0021-9010.72.3.374

Estelami, H. (2000). Competitive and procedural determinants of delight and disappointment in consumer complaint outcomes, Journal of Service Research, 2(3), 285-300. http://dx.doi.org/10.1177/109467050023006

Gummesson, E. (1993). Quality Management in Service Organization: An Interpretation of the Service Quality Phenomenon and a Synthesis of International Research. Karlstad: International Service Quality Association.

Hackman, J. R., \& Oldham, G. R. (1980). Work Redesign. Addison-Wesley, Reading, MA.

Hallowell, R. (1996). The relationships of customer satisfaction, customer loyalty, and profitability: an empirical study. International Journal of Service Industry Management, 7(4), 27-42. http://dx.doi.org/10.1108/09564239610129931

Heskett, J. L., Jones, T. O., Loveman, G. W., Sasser, W. E. Jr., \& Schlesinger, L. A. (1994). Putting the service-profit chain to work. Harvard Business Review, March-April, 164-74.

Heskett, J. L., Sasser, W. E. Jr., \& Schlesinger, L. A. (1997). The Service Profit Chain. New York, NY: The Free Press.

Hom, P. W., \& Griffeth, R. W. (1995). Employee Turnover. South-Western, Cincinnati, OH.

Jacoby, J., \& Kyner, D. B. (1973). Brand loyalty vs. repeat purchasing behavior. Journal of Marketing Research, February, 1-9. http://dx.doi.org/10.2307/3149402

Jones, T. O., \& Sasser, W. E. (1995). Why satisfied customers defect? Harvard Business Review, November-December, 88-99.

Lau, R. S. M. (2000). Quality of work life and performance-An ad hoc investigation of two key elements in the service profit chain model. International Journal of Service Industry Management, 11(5), 64-43. http://dx.doi.org/10.1108/09564230010360164

Locke, E. E. (1976). The nature and causes of job satisfaction. In Dunnette, M. D. (Ed.), Handbook of Industrial and Organizational Psychology (pp. 1297-349). Rand McNally, Chicago, IL.

Loveman, G. W. (1998). Employee satisfaction, customer loyalty, and financial performance: an empirical examination of the service profit chain in retail banking. Journal of Service Research, 1(1), 18-31. http://dx.doi.org/10.1177/109467059800100103

Oliver, R. L. (1997). Satisfaction: A Behavioral Perspective on the Consumer. New York, NY: McGraw-Hill. 
Reichheld, F. F. (1993). Loyalty-based management. Harvard Business Review, March-April, 64-73.

Reichheld, F. F., \& Sasser, W. E. (1990). Zero defections: quality comes to services. Harvard Business Review, September-October, 105-11.

Russi, A. J., Krin, S. P., \& Quinn, R. T. (1998). The employee-customer-profit chain at Sears. Harvard Business Review, January-February, 83-97.

Rust, R. T., \& Stewart, G. L. (1996). The satisfaction and retention of frontline employees: a customer satisfaction measurement approach. International Journal of Service Industry Management, 7(5), 62-80. http://dx.doi.org/10.1108/09564239610149966

Schlesinger, L. A., \& Zornitsky, J. J. (1991). Job satisfaction, service capability and customer satisfaction: an examination of linkages and management implications. Human Resource Planning, 14(2), 141-9.

Steel, R. P., \& Ovalle, N. K. II. (1984). A review and meta-analysis of research on the relationship between behavioral intentions and employee turnover. Journal of Applied Psychology, 69, 673-86. http://dx.doi.org/10.1037/0021-9010.69.4.673

Storbacka, K., Strandvik, T., \& Gronroos, C. (1994). Managing customer relationships for profit: the dynamics of relationship quality. International Journal of Service Industry Management, 5(5), 21-38. http://dx.doi.org/10.1108/09564239410074358

Yadollah mehralizadeh, \& Chinese processor, Rahim. (2005). The statistical data analysis techniques and test hypotheses in social sciences and management with SPSS software in Windows. Tehran, Iran: Aizh publication.

Yi, Y. (1990). A critical review of consumer satisfaction. In Zeithaml V. (Ed.), Review of Marketing (pp. 68-123). American Marketing Association, Chicago, IL.

Table 1. Indices used for measurement of variables

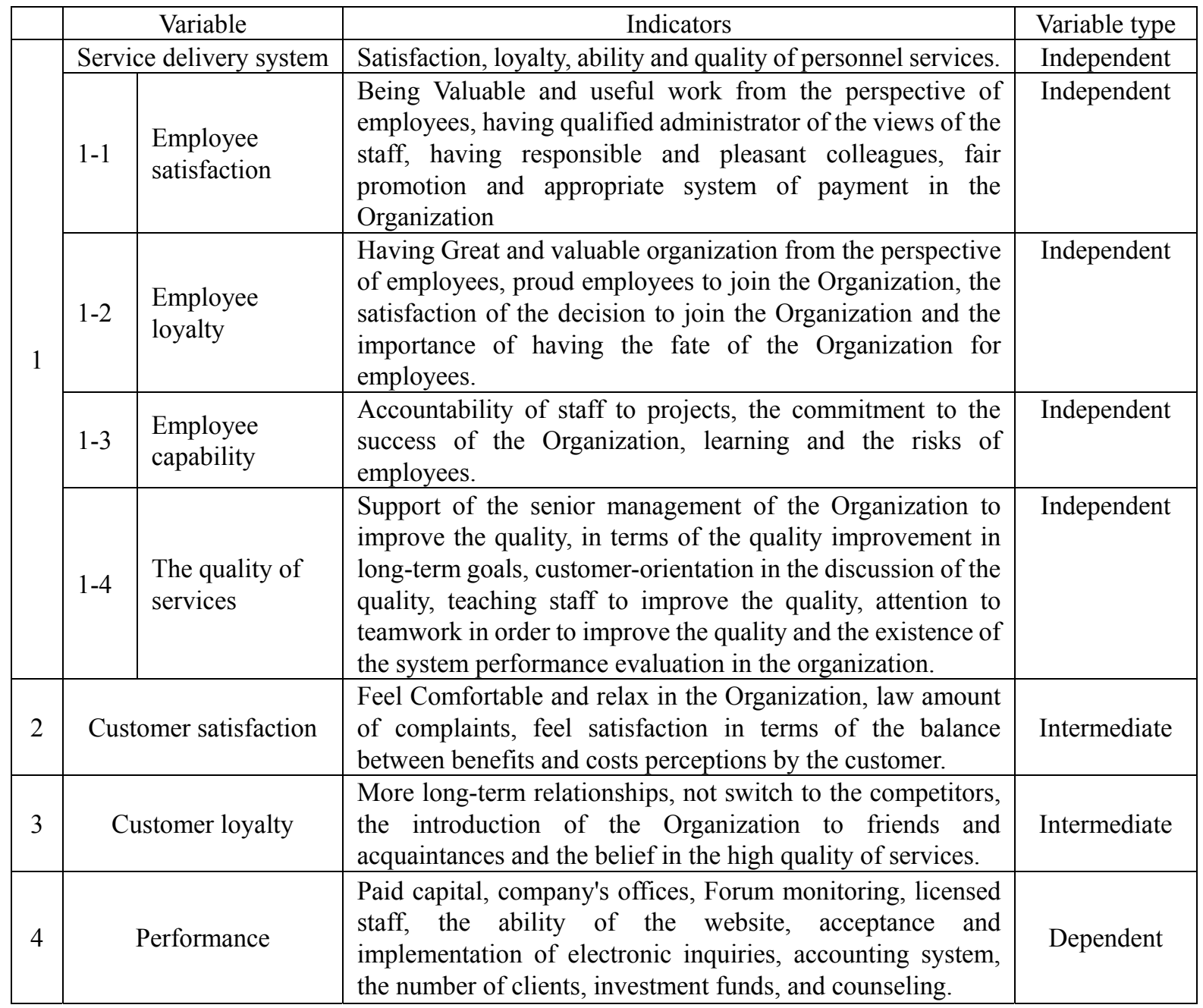


Table 2. Reliability Statistics

\begin{tabular}{|c|c|}
\hline Cronbach's Alpha & N of Items \\
\hline 0.838 & 28 \\
\hline
\end{tabular}

Table 3. Results of regression analysis for customer satisfaction

\begin{tabular}{|c|c|c|c|c|}
\hline \multicolumn{5}{|c|}{ Model Summary } \\
\hline Model & R & R Square & Adjusted R Square & Std. Error of the Estimate \\
\hline 1 & $0.736^{\mathrm{a}}$ & 0.541 & 0.492 & 0.42083 \\
\hline
\end{tabular}

\begin{tabular}{|c|c|c|c|c|c|c|}
\hline \multicolumn{7}{|c|}{ ANOVA } \\
\hline \multicolumn{2}{|r|}{ Model } & Sum of Squares & $\mathrm{df}$ & Mean Square & $\mathrm{F}$ & Sig. \\
\hline \multirow{3}{*}{1} & Regression & 7.729 & 4 & 1.932 & 10.910 & 0.000 \\
\hline & Residual & 6.553 & 37 & 0.177 & & \\
\hline & Total & 14.281 & 41 & & & \\
\hline
\end{tabular}

\begin{tabular}{|c|c|c|c|c|c|c|c|c|}
\hline \multicolumn{9}{|c|}{ Coefficients } \\
\hline & \multirow[t]{2}{*}{ Model } & \multicolumn{2}{|c|}{$\begin{array}{l}\text { Unstandardized } \\
\text { Coefficients }\end{array}$} & \multirow{2}{*}{$\begin{array}{c}\text { Standardized } \\
\text { Coefficients } \\
\text { Beta } \\
\end{array}$} & \multirow[t]{2}{*}{$\mathrm{t}$} & \multirow[t]{2}{*}{ Sig. } & \multicolumn{2}{|c|}{$\begin{array}{l}\text { Collinearity } \\
\text { Statistics }\end{array}$} \\
\hline & & $\mathrm{B}$ & Std. Error & & & & Tolerance & VIF \\
\hline \multirow{5}{*}{1} & (Constant) & -1.491 & 0.961 & & -1.551 & 0.129 & & \\
\hline & Employee satisfaction & 0.415 & 0.172 & 0.303 & 2.421 & 0.020 & 0.792 & 1.263 \\
\hline & Employee loyalty & 0.294 & 0.257 & 0.154 & 1.146 & 0.259 & 0.686 & 1.459 \\
\hline & Employee capability & 0.366 & 0.137 & 0.380 & 2.669 & 0.011 & 0.611 & 1.637 \\
\hline & quality of services & 0.278 & 0.214 & 0.173 & 1.302 & 0.201 & 0.700 & 1.429 \\
\hline
\end{tabular}

Table 4. Results of regression analysis for customer loyalty

\begin{tabular}{|c|c|c|c|c|}
\hline \multicolumn{5}{|c|}{ Model Summary } \\
\hline Model & R & R Square & Adjusted R Square & Std. Error of the Estimate \\
\hline 1 & 0.890 & 0.793 & 0.770 & 0.23778 \\
\hline
\end{tabular}

\begin{tabular}{|c|c|c|c|c|c|c|}
\hline \multicolumn{7}{|c|}{ ANOVA } \\
\hline & Model & Sum of Squares & $\mathrm{df}$ & Mean Square & $\mathrm{F}$ & Sig. \\
\hline \multirow{3}{*}{1} & Regression & 7.991 & 4 & 1.998 & 35.337 & $.000^{\mathrm{a}}$ \\
\hline & Residual & 2.092 & 37 & .057 & & \\
\hline & Total & 10.083 & 41 & & & \\
\hline
\end{tabular}

\begin{tabular}{|c|c|c|c|c|c|c|}
\hline \multicolumn{9}{|c|}{ Coefficients } \\
\hline \multirow{2}{*}{ Model } & Unstandardized Coefficients & Standardized Coefficients & \multirow{2}{*}{$\mathrm{t}$} & \multirow{2}{*}{ Sig. } \\
\cline { 2 - 7 } & B & Std. Error & Beta & & \\
\hline \multirow{4}{*}{1} & (Constant) & -0.682 & 0.543 & & -1.256 & 0.217 \\
\cline { 2 - 7 } & Employee satisfaction & 0.309 & 0.097 & 0.268 & 3.188 & 0.003 \\
\cline { 2 - 7 } & Employee loyalty & 0.096 & 0.145 & 0.060 & 0.663 & 0.512 \\
\cline { 2 - 7 } & Employee capability & 0.488 & 0.078 & 0.603 & 6.293 & 0.000 \\
\cline { 2 - 7 } & quality of services & 0.315 & 0.121 & 0.234 & 2.610 & 0.013 \\
\hline
\end{tabular}


Table 5. Results of regression analysis for the performance of brokerage active in the stock exchange

\begin{tabular}{|c|c|c|c|c|}
\hline \multicolumn{5}{|c|}{ Model Summary } \\
\hline Model & R & R Square & Adjusted R Square & Std. Error of the Estimate \\
\hline 1 & 0.865 & 0.749 & 0.736 & 22.43229 \\
\hline
\end{tabular}

\begin{tabular}{|c|c|c|c|c|c|c|}
\hline \multicolumn{9}{|c|}{ ANOVA } \\
\hline \multirow{2}{*}{1} & Model & Sum of Squares & df & Mean Square & F & Sig. \\
\hline & Regression & 58482.313 & 2 & 29241.157 & 58.110 & 0.000 \\
\cline { 2 - 7 } & Residual & 19625.091 & 39 & 503.207 & & \\
\cline { 2 - 8 } & Total & 78107.405 & 41 & & & \\
\hline
\end{tabular}

\begin{tabular}{|c|c|c|c|c|c|c|c|c|}
\hline \multicolumn{9}{|c|}{ Coefficients } \\
\hline & \multirow{2}{*}{ Model } & \multicolumn{2}{|c|}{$\begin{array}{l}\text { Unstandardized } \\
\text { Coefficients }\end{array}$} & \multirow{2}{*}{\begin{tabular}{|c|}
$\begin{array}{c}\text { Standardized } \\
\text { Coefficients }\end{array}$ \\
Beta \\
\end{tabular}} & \multirow{2}{*}{$\mathrm{t}$} & \multirow[t]{2}{*}{ Sig. } & \multicolumn{2}{|c|}{$\begin{array}{l}\text { Collinearity } \\
\text { Statistics }\end{array}$} \\
\hline & & B & Std. Error & & & & Tolerance & VIF \\
\hline \multirow{3}{*}{1} & (Constant) & $\begin{array}{c}-133.72 \\
9\end{array}$ & 26.212 & & -5.102 & 0.000 & & \\
\hline & Customer satisfaction & 56.685 & 10.160 & 0.644 & 5.579 & 0.000 & 0.556 & 1.56 \\
\hline & Customer loyalty & 20.523 & 8.538 & 0.278 & 2.404 & 0.021 & 0.556 & 1.56 \\
\hline
\end{tabular}

Table 6. Hypotheses testing results

\begin{tabular}{|c|c|c|c|}
\hline Hypothis symbol & Independent Variable & Dependant Variable & Testing Result \\
\hline H1 & Service delivery system & \multirow{5}{*}{$\begin{array}{c}\text { The level of customer } \\
\text { satisfaction. }\end{array}$} & Accepted \\
\hline $\mathrm{H} 2$ & Employee satisfaction & & Accepted \\
\hline H3 & Employee loyalty & & Rejected \\
\hline $\mathrm{H} 4$ & Employee capability & & Accepted \\
\hline H5 & Quality of services & & Rejected \\
\hline H6 & Service delivery system & \multirow[t]{5}{*}{ the level of customer loyalty } & Accepted \\
\hline $\mathrm{H} 7$ & Employee satisfaction & & Accepted \\
\hline $\mathrm{H} 8$ & Employee loyalty & & Rejected \\
\hline H9 & Employee capability & & Accepted \\
\hline H10 & Quality of services & & Accepted \\
\hline H11 & $\begin{array}{c}\text { The level of customer } \\
\text { satisfaction }\end{array}$ & $\begin{array}{c}\text { the level of brokerage } \\
\text { performance }\end{array}$ & Accepted \\
\hline H12 & the level of customer loyalty & $\begin{array}{c}\text { the level of brokerage } \\
\text { performance }\end{array}$ & Accepted \\
\hline
\end{tabular}




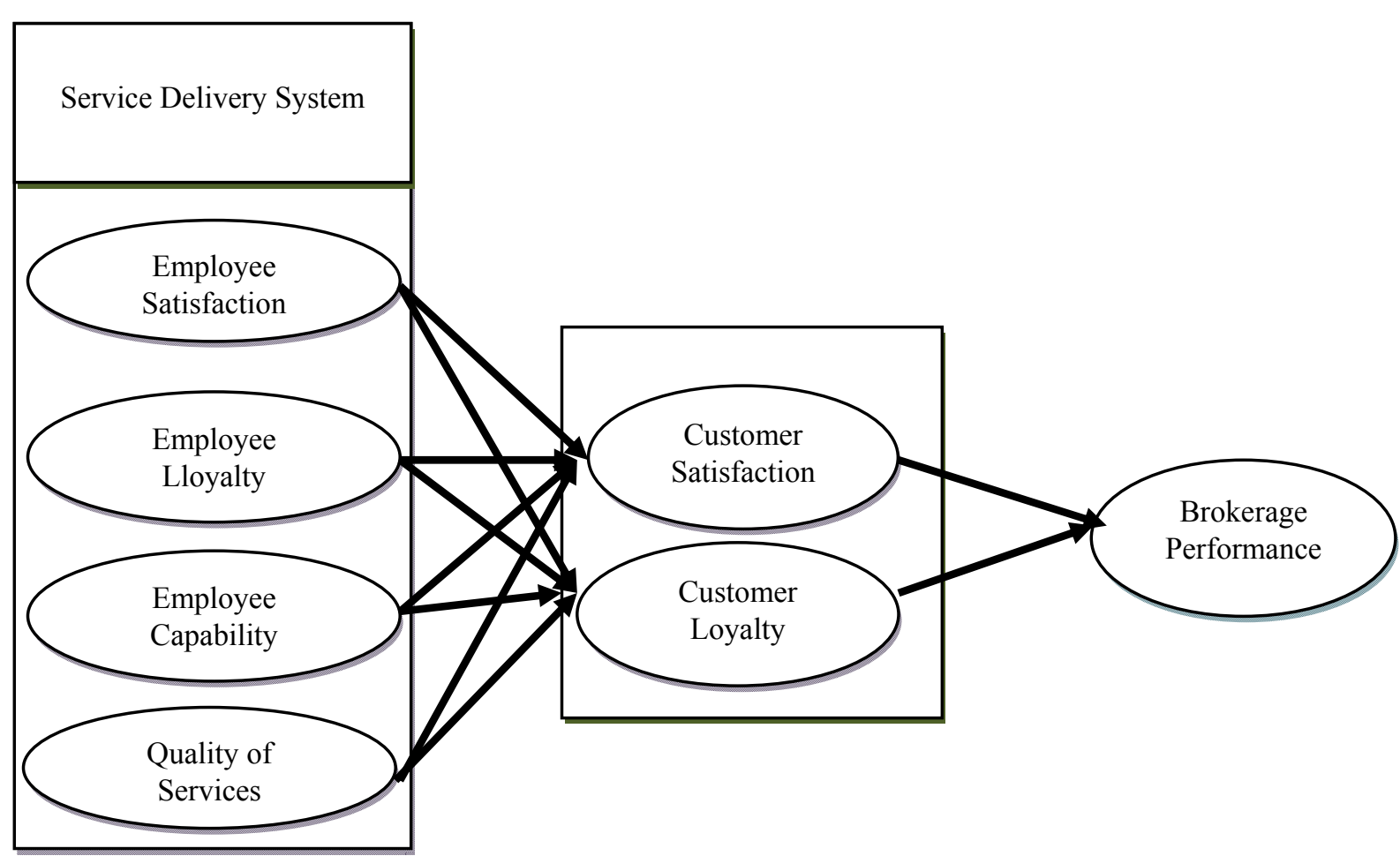

Figure 1. Research conceptual model 